\title{
The intention to quit entrepreneurship in tourism SMEs: The effect of work addiction
}

\author{
Agustín J. Sánchez-Medina ${ }^{\mathrm{a}, *}$, Jesús Arteaga-Ortiz ${ }^{\mathrm{b}}$, Rodrigo M. Naumchik ${ }^{\mathrm{b}}$, Mónica Pellejero ${ }^{\mathrm{c}}$ \\ ${ }^{\text {a }}$ University Institute for Cybernetic Science and Technologies, University of Las Palmas de Gran Canaria, Despacho C-2.21, Ed. de Económicas y Empresariales, Campus de \\ Tafira, 35017 Las Palmas de Gran Canaria, Spain \\ ${ }^{\mathrm{b}}$ Faculty of Economics, Business and Tourism. University of Las Palmas de Gran Canaria, Despacho C-3.11, Ed. de Económicas y Empresariales, Campus de Tafira, 35017 \\ Las Palmas de Gran Canaria, Spain \\ ${ }^{\mathrm{c}}$ Mid Atlantic University, Carretera de Quilmes, 37, 35017 Tafira Baja, Las Palmas de Gran Canaria, Spain
}

\section{A R T I C L E I N F O}

\section{Keywords:}

Tourism entrepreneurship

SME

Business failure

Workaholism

Work addiction

Work enjoyment

Work involvement

\begin{abstract}
A B S T R A C T
Entrepreneurship is one of the fundamental tools in the generation of economic activity and labor in the tourism industry, with Small and Medium Enterprises (SMEs) playing a relevant role in the sector. Academic studies on entrepreneurship have focused more on the keys to entrepreneurial success, rather than on the factors leading to its abandonment. In the tourism sector, the lack of research on this matter is even more significant. In response to this gap in literature, this article aims to be a first approach to the study of work addiction as an antecedent of entrepreneurial abandonment. The main contribution of this study confirms the relationship between the different constructs that relate work addiction to entrepreneurship withdrawal. Thus, hypotheses relating driveness and lack of work enjoyment to the intention to quit entrepreneurship are supported. The hypothesis relating work involvement with the intention to quit is not supported, however. A number of important implications derive from this study. Among them, our results demonstrate that the relationship between workaholism and the intention to quit entrepreneurship in the tourist SME sector is supported, and that work enjoyment can act as a mediator strengthening the effect of the driveness to work on the intention to quit.
\end{abstract}

\section{Introduction}

Hardly anyone doubts the importance of entrepreneurship on the economic development of different regions of the world (Acs et al., 2018; Breitenecker et al., 2017; Ferreira et al., 2019). Its importance is well accepted within the academic community, where entrepreneurship is now one of its major fields of study (Busenitz et al., 2003; Ferreira et al., 2019; Gartner, 2001). The main lines of study have typically covered entrepreneurship success, focusing on topics such as training (Amorós and Cristi, 2008; Fayolle and Gailly, 2015; Lee et al., 2005), personal and demographic characteristics of the entrepreneur (Lee and Lee, 2015; Mas-Tur et al., 2015; Sajilan et al., 2015; Palmer et al., 2019), entrepreneurial orientation (Kallmuenzer et al., 2018; Peters et al., 2010) and the relationship between entrepreneurship and aspects such as innovation (Arshi and Burns, 2018), economic growth (Acs and Szerb, 2007; Galindo and Méndez, 2014), job creation (Decker et al., 2014) and development (Acs et al., 2008; Schumpeter, 1934).

In the academic world, entrepreneurial success is studied exhaustively; however, failure has been relatively ignored (Heinze, 2013). In this sense, Blackburn and Kovalainen (2009) categorize this phenomenon as a fertile area of research. Moreover, the reality of entrepreneurship should not be overlooked, which, in most cases, is far from being a story of success and positive results. Thus, around half of new companies fail during their first two years of life (Cressy, 2006). A study performed in Spain between 2010-2015 reveals that around 25\% of the companies created in that timeframe had dissolved within a year, between $30 \%$ and $35 \%$ within two years, and almost half at three years (INE, 2015).

One of the possible determinants for this entrepreneurial failure is due to the entrepreneur. As stated by Palmer et al. (2019, pp.185), the entrepreneur is critical to the survival and development of SMEs by shaping their strategy, culture and actions. Some authors even consider the companies to be extensions of their founders (Brüderl et al., 1992; Brüderl and Preisendörfer, 1998; Chandler and Jansen, 1992; Van de Ven et al., 1984).

As a consequence, the effects of entrepreneur's characteristics on

\footnotetext{
* Corresponding author.

E-mail addresses: agustin.sanchez@ulpgc.es (A.J. Sánchez-Medina), jesus.arteaga@ulpgc.es (J. Arteaga-Ortiz), rodrigo.naumchik@ulpgc.es (R.M. Naumchik), monica.pellejero@atlanticomedio.es (M. Pellejero).
} 
firm performance have been greatly studied (Lee, 2019; Unger et al., 2011; Van Ness and Seifert, 2016). One the one hand, the impact of the demographic characteristics of the entrepreneur on performance have been extensively analised (Sajilan et al., 2015), covering aspects such as age (eg. Priede-Bergamini et al., 2019; Zhang and Acs, 2018) and gender (eg. Artz, 2017; Hallak et al., 2015).

On the other hand, the psychology of the entrepreneur presents a vast body of research because of how psychology affects entrepreneurs' behaviour and actions during the entrepreneurial process (Davidsson and Wiklund, 2001; Omorede et al., 2015; Wiklund et al., 2011). The five main fields of study in entrepreneur psychology are personality, cognition, emotion, attitude and self (Omorede et al., 2015; Shaver, 2003), of which personality, cognition and attitude have seen the most attention (Omorede et al., 2015).

Centering on the first of these three fields of entrepreneur psychology, the entrepreneur's personality traits' effect on performance is a topic of great importance (Kerr et al., 2018; Zhao et al., 2010), due to its ability to explain entrepreneur success in all its areas (economic, social, personal and societal) (Gorgievski and Stephan, 2016). Originally, entrepreneur personality research focused on finding what personality traits defined an entrepreneur, and what effect they had on performance (Omorede et al., 2015). In recent years, a big part of the research on entrepreneur personality has revolved around the personality Big Five (extroversion, agreeableness, conscientiousness, neuroticism and openness to experience) (Omorede et al., 2015), first proposed by Goldberg (1990).

Following personality, cognition focuses on the knowledge structures used by entrepreneurs to analyze, judge or decide in relation to business opportunities and venture creation (Mitchell et al., 2002). According to Omorede et al. (2015), the three main areas of study in this field are entrepreneurial intentions (capacity to recognize opportunities), the definition of an entrepreneur (how are entrepreneurs different from non-entrepreneurs) and entrepreneur's success. For example, following this line of study, entrepreneur's self-efficacy, the belief of being capable of accomplishing a task, has been linked to increased performance (Hallak et al., 2015; McGee et al., 2009; Miao et al., 2017), while risk-propensity is considered a key aspect of entrepreneurs (Block et al., 2015; Herranz et al., 2015) which helps them face recognized business opportunities (Lago et al., 2018).

Finally, attitude research focuses on the determination of individual intentions toward entrepreneurial behaviour, and the Theory of Planned Behaviour, proposed by Ajzen (1991) is a central point in this field (Omorede et al., 2015). The Theory of Planned Behaviour (Ajzen, 1991) explains how behavioural intentions are influenced by the perceived behavioural control (the expectations to have a positive outcome) to become a behaviour. In this area, many researchers focus on the establishment of what attitudes act as a precursor to self-employment (eg. Kolvereid and Isaksen, 2006) and entrepreneurship (eg. Wurthmann, 2014; Zhang et al., 2014).

On another level, in the words of Fu et al. (2019) and Rumelt (1991), entrepreneurship is closely linked to every industry, which greatly influences the strategies that should be followed. Tourism is no exception to this, and it requires study because it is the principal sector in the service industry, thanks to the number of people it employs and its impact on the development of the regions, both from a social and economic perspective (Ahmad, 2015).

As a field of study, tourism entrepreneurship went from having a few published articles in the 1970s and 1980s under the business economics category, to being a body of literature on its own, with studies increasing in number and diversity (Carmichael and Morrison, 2011). However, according to Solvoll et al. (2015, pp. 121), in their theoretical review of the publications on tourism entrepreneurship, "until recently, only a small proportion of the articles on tourism have been related to entrepreneurship issues."

Solvoll et al. (2015) state that, when studying entrepreneurship in the case of tourism, some works follow a convergent approach, studying concepts related to general entrepreneurship under the tourism sector (like the lines of study mentioned above), while other works follow a divergent strategy, where authors study tourism entrepreneurship as a unique and distinct activity, focusing on its specificities. Under this second approach, works cover topics such as the importance of place and destination (Daskalopoulou and Petrou, 2009), the motivation for starting a business in the tourism sector (Di Domenico and Miller, 2012) and the importance of the tourism entrepreneur in destination management (Strobl and Peters, 2013).

Studying tourism entrepreneurship research as a whole, Fu et al. (2019), in their study of 22 years of entrepreneurship research in hospitality and tourism, divide the research domains into four main topics: the "person aspect," "destination environment," "firm growth," and "destination development." Under this classification, the person aspect and destination environment domains are the most researched topics, with $38 \%$ and $35 \%$ of the total works, respectively.

Entrepreneurial behavior has received increasing attention in tourism research (Ahmad, 2015). This area of research focuses on such aspects as the role an entrepreneur plays in destination development (Strobl and Peters, 2013), where entrepreneurship is seen as a driver for destination and tourism development (Peters and Kallmuenzer, 2018) and small business entrepreneurs serve as "cultural brokers within host communities" (Shaw, 2008, pp. 125).

Moreover, the typology of tourism entrepreneurs is another important topic, where tourism entrepreneurship is usually seen as a separate category, commonly referred to as lifestyle entrepreneurship (Bredvold and Skålén, 2016). While a lifestyle entrepreneur is generally considered to focus on balancing economic, family and social needs (Jaafar et al., 2011), and make business decisions on a more subjective basis than his general entrepreneur counterpart (Dewhurst and Horobin, 1998), researchers have identified this type of entrepreneurship as heterogeneous, thus highlighting the need to give special attention to the specificities of the tourism entrepreneur (Thomas et al., 2011).

Finally, another important topic of study in tourism entrepreneurial behavior is the relevance of entrepreneurial orientation for firm performance (Peters and Kallmuenzer, 2018). Under this view, successful entrepreneurial behavior consists of the interaction of three variables innovativeness, proactiveness and risk-taking (Covin and Slevin, 1989) - with the internal effect of firm factors, and the external effect of networks and environmental circumstances (Köseoglu et al., 2013; Peters and Kallmuenzer, 2018).

The growing interest shown in the specific characteristics and motivations of tourism entrepreneurship (Peters and Kallmuenzer, 2018), highlights the need for further development of research on the characteristics and motivations of the tourism entrepreneur as a crucial factor in the success or failure of small businesses (Kallmuenzer and Peters, 2018).

In light of the above, this article aims to bridge an existing gap in the tourism literature on entrepreneurial failure, more specifically the withdrawal from activities, as highlighted by DeTienne and Wennberg (2016), through the study of the motivations behind the withdrawal from entrepreneurial activities. More specifically, we examine how the different constructs elaborated by Spence and Robins (1992) confirm the influence of work addiction on the intention to quit.

In addition, the study will focus on the SME entrepreneur since, as Hallak et al. (2015) state, these companies play a very relevant role on the different tourist destinations in job creation, economic and image stimulus, and sustainable development of the destination. Moreover, the economies of many countries include a large proportion of tourism SMEs (Pikkemaat et al., 2018), thus increasing the relevance of our study.

Furthermore, it is in this type of business, as stated above, where the entrepreneur's figure has the greatest influence over management and results (Lee and Lee, 2015; Palmer et al., 2019; Wiklund et al., 2009). This approach is unique, not only because of the issue it covers - the 
relationship between work addiction and the abandonment of entrepreneur activity - but also because of the area in which it occurs, SMEs in the tourism sector.

In this sense, we argue that the study of psychological factors affecting the entrepreneur can make a contribution to the understanding of entrepreneurial behavior, in the withdrawal from activities to be more precise, in tourism SMEs.

Moreover, the present article highlights the importance of an area of growing recognition in entrepreneurship research, the research on entrepreneur's mental health and well-being (Levasseur et al., 2019; Stephan, 2018; van der Zwan et al., 2018). Studies on entrepreneur's mental health and well-being cover topics such as the higher levels of stress entrepreneurs suffer as opposed to employees, the effects of these higher stress levels and how different types of entrepreneur show different states of mental health and well-being (Stephan, 2018).

It's important to mention that the current article is of interest to different stakeholders in the tourism sector. First, for entrepreneurs, since it analyzes a determinant of failure for entrepreneur initiatives. Second, for the tourist destination, since the problems of these companies can translate into worse service given and, consequently, a deterioration of the destination's image. Third, it is important for public administrations in a double way. On the one hand, because of the huge amount of money invested in promoting business creation; on the other, because of the effects of entrepreneur failure in terms of economic deterioration, sector image and job destruction. Fourth, and finally, it's critical to note the effect of the abandonment of the entrepreneur on their providers and/or clients.

\section{Theoretical review}

\subsection{Workaholism}

According to Clark et al. (2016), work addiction, also known as workaholism, is a topic of great academic interest with an important increase in its study since year 2000. These authors, in their metaanalysis of publications on workaholism, affirm that, in spite of the mentioned increase in studies in this area, the topic is still surrounded by confusion regarding its definition, conceptualization and measurement.

In this sense, there is no agreed-upon definition on the work addiction, or workaholism concept (Clark et al., 2016; Harpaz and Snir, 2003; Moreno-Jiménez et al., 2005; Robinson, 2000), despite a substantial number of publications on this phenomenon (eg. Brett and Stroh, 2003; Burke, 2000; Harpaz and Snir, 2003). Oates (1971), the author known for giving birth to the workaholism term, defines it as "the compulsion or uncontrollable need to work incessantly" (Oates, 1971, pp. 11). According to said author, it is a type of behavior observed in the worker's conduct, similar to alcoholism due to its compulsive and uncontrollable character. At the same time, it can become a risk for the personal health, happiness, interpersonal relations and social capacities of the individual.

In the same vein, Schaufeli et al. (2008, pp. 204) consider it "the tendency to compulsively work too hard." According to MorenoJiménez et al. (2005), workaholism, or work addiction, manifests when work hours increase considerably, occupying most of the individual's time, who then acquires a compulsive dedication and seems to define himself based exclusively on work, being unable to enjoy other aspects of life. Cherrington (1980) defines it as an irrational predilection towards excessive working that characterizes people who are unable to find occupations other than their job. Spence and Robbins (1992) consider it to be a high predilection towards work due to internal pressures and a low capacity to enjoy work. Similarly, Snir and Harpaz (2004, pp. 522) typify it as "an individual's steady and considerable allocation of time to work related activities and thoughts, which does not derive from external necessities." Killinger (1991) defines work addiction as the gradual loss of emotional stability which transforms into an addiction to control and power in a compulsive search for approval and success. In this vein, Robinson (1997) affirms it is a continuous, voluntary and compulsive work overcharge, in such a way that the worker is incapable of regulating his work habits and ends up excluding other areas of interest and activity. Salanova et al. (2008, pp. 1) define work addiction as "psychosocial damage characterized by excessive work, mainly due to an irresistible need or impulse to constantly work." Finally, it is interesting to note that Piotrowski and Vodanovich (2006) state that the work addiction syndrome affects the individual's satisfaction, both on his work and family environment. Therefore, those who suffer from it can create negative effects on their work performance (eg. Mudrack and Naughton, 2001; Porter, 1996; Spence and Robbins, 1992).

As seen, definitions of workaholism are multiple and, in many cases, present substantial differences. Moreover, there is no consensus when categorizing this phenomenon. Some authors talk about addiction (Porter, 2006), others categorize it as a syndrome (Aziz and Zickar, 2006) and, with not so negative connotations, some authors consider it a behavioral pattern (Scottl et al., 1997).

Although addictions are generally viewed in an unfavorable light, this is not the case with work-related addictions, which sometimes have social and economic reinforcements (Moreno-Jiménez et al., 2005), even though they can have negative consequences on the health and productivity of those who suffer from it. While authors like Korn et al. (1987); Naughton (1987) and Sprankle and Ebel (1987) refer to workaholism as a positive behavior which may even benefit the organization, according to Del Líbano et al. (2010) most authors treat this phenomenon negatively, under the same consideration as any addiction (eg. Gorgievski et al., 2010; Oates, 1981; Porter, 1996; Taris et al., 2008).

Starting with the fact that, today, most scholars categorize workaholism as an addiction (Clark et al., 2016), numerous authors study this phenomenon and create scales to measure it. The main scales used to measure workaholism are the Workaholism Battery (Spence and Robbins, 1992), the Work Addiction Risk Test (Robinson, 1989) and the Dutch Workaholism Scale (Schaufeli et al., 2009).

The work by Spence and Robins (1992) has been, according to $\mathrm{Ng}$ et al. (2007), one of the most cited models in the study of workaholism and continues to be, nowadays, one of the main references on this subject. The authors present three measurable variables: Driveness, Work involvement and Work enjoyment, from which profiles can be made to identify the different worker typologies. Under this theory, the workaholic is that person who presents a high grade of driveness and work involvement, together with a low grade of work enjoyment.

\subsection{Driveness}

"The cognitive dimension of workaholism reflects those intellectual processes that propel workaholics to work excessively. We suggest that the core cognitive element characterizing workaholism is an obsession with working" (Ng et al., 2007, pp. 115).

The first variable in the workaholism triad is driveness. Spence and Robbins (1992, pp. 161) define this property as that which "compels a person to work, not because of pleasure or external demands, but because of inner pressures which make the person guilty or distressed when not working." This factor is key in the definition of workaholism since it describes its behavior as an addiction.

Furthermore, Schaufeli et al. (2008) talk about a strong, irresistible inner drive which pushes individuals to work compulsively. This obsessive character is one of the reasons why workaholism resembles alcoholism. These authors state that, typically, the workaholic works way more than necessary or expected, not to obtain some reward or fight for his career, but because of an inner compulsion, need or drive. In this sense, a person with a high driveness to work will feel a need to work, thus having a high work involvement. This motivation to reach high work rates because of inner impulses rather than rational motivations 
(financial or career related) differentiates a workaholic from a work enthusiast (Schaufeli et al., 2009).

Thus, the following hypothesis is proposed:

H1. An entrepreneur's driveness to work has a positive effect on his work involvement.

This obsessive conduct towards work can also affect its enjoyment. $\mathrm{Ng}$ et al. (2007) add that the workaholic does not expect joy in work, they, instead, enjoys the act of working. This focus placed on the act, rather than the nature of work, can push the person to persist with work they are unable to enjoy. A similar approach is followed by Spence and Robins (1992), who consider that in a workaholic there is a relation between the compulsion to work and a low degree of work enjoyment. In addition, authors like Burke and MacDermid (1999), in their study of the relationship between these three variables through the analysis of managers, determined that those managers who felt a deeper driveness were less satisfied with their job and career.

Thus, the following hypothesis is proposed:

H2. An entrepreneur's driveness to work has a positive effect on his lack of work enjoyment.

\subsection{Work involvement}

"The individual who is highly work-involved characteristically devotes himself or herself wholeheartedly to productive projects and prefers to make constructive uses of time" (Spence and Robins, 1992, pp. 162). This factor relates to the work charge and the way the individual approaches work, affecting not only his specific job but sometimes his whole life.

Jans (1982) defines work involvement as a three-dimensional concept involving the person's orientation towards work (personality), the identification with the job (motivation) and the identification with the career (performance to self-esteem relationship).

In the workaholism context, a person with a high driveness to work will probably have a high work involvement, but a person with a high work involvement doesn't necessarily need to have a high driveness to work. Schaufeli et al. (2009) differentiate between two profiles which could be confused: real workaholism and the work enthusiast. They both present a high grade of work involvement but, while the workaholic has high driveness and low work enjoyment, the work enthusiast has low driveness and high work enjoyment. The key to this difference lies in the motivation to work.

Burke (2006) adds that, compared to the true workaholic, the work enthusiast presents lower levels of stress, is more satisfied with his work, career and leisure time, has less psychosomatic problems and has a smaller likelihood of quitting.

Nevertheless, in relation to the effects of work involvement, Salanova et al. (2008) state that this excessive work charge damages the person, who does not feel well and sees how stress and psychological discomfort increase. This situation can also have an effect on the social, performance and domestic environments.

Based on the previous arguments, the following hypothesis is proposed:

H3. An entrepreneur's work involvement has a positive effect on his lack of work enjoyment.

\subsection{Work enjoyment}

"Enjoyment of work is the degree to which individuals work because they find the work itself intrinsically interesting or pleasurable." (Graves et al., 2012, pp. 1660). According to these authors, work enjoyment reduces work's psychological damage, increases career satisfaction, performance and the degree to which the subject will fight for his objectives.
Despite the importance given to this factor by Spence and Robins (1992) when defining workaholism, it has received criticism due to it being an intrinsic part of workaholism's definition. In this vein, Mudrack (2006) argues that a workaholic can enjoy work or not, thus work enjoyment is not a basic element of workaholism. In contrast to this opinion, Kanai and Wakabayashi (2004) affirm that faced with adversities the lack of enjoyment is strengthened, generating problems derived from workaholism.

\subsection{Intention to quit}

Once the variables are defined and the relationships between them proposed, in order to address the central objective of this work the effect of each of these variables on the intention to quit was studied.

As a starting point, the work of Burke and MacDermid (1999) studies the relationships between the three variables, as well as their effect on four other variables: career satisfaction, career prospects, job satisfaction and intent to quit. Results show work enjoyment as the only variable with a direct (negative) relationship with the intention to quit. Nevertheless, both driveness and work involvement show significant correlations with career satisfaction, career prospects, job satisfaction and work enjoyment, which are indeed significant to the intention to quit.

In the case of driveness to work, Burke (2006) states that those people with high work involvement, motivated by high work enjoyment instead of high driveness to work, present higher satisfaction with both work and life, have better physical and emotional stability and show less intention to quit. From this statement we can conclude that driveness is a clear determinant when predicting the intention to quit.

Based on the previous arguments, we present the following hypothesis:

H4. An entrepreneur's driveness to work has a positive effect on his intention to quit.

The study of work involvement is a completely different case. The principle of the definition of workaholism revolves around one concept: a very high workload motivated by an addiction to work ( $\mathrm{Ng}$ et al., 2007). When studying a high workload on its own, without the inner motive to work concept, the worker might not necessarily present problems deriving from an intention to quit. In this respect, $\mathrm{Ng}$ et al. (2007) clarify that, in the case of a workaholic, excessive work hours are a manifestation of the addiction, while a person without such addiction will have a real motivation to work in excess (organizational motives, financial needs, etc.).

Lastly, theories covering work engagement make an important contribution in this regard. Work engagement is a positive, fulfilling, work-related state of mind, characterized by vigor, dedication and engagement, where an individual feels united to his work (Schaufeli et al., 2002). According to these authors, unlike workaholism, an engaged individual will not present an addiction and, although working too hard, will also know how to enjoy free time and maintain healthy parameters regarding work and rest.

With regard to the above mentioned, the following hypothesis is established:

H5. An entrepreneur's work involvement has a negative effect on his intention to quit.

Finally, in the case of work enjoyment, there is consensus around its positive effect on the individual and his resistance to adversities, as previously stated. In the study of the effects of work enjoyment as a motivation to work in the specific case of company managers, Graves et al. (2012) prove this factor to be critical for the effectiveness, performance and satisfaction of a manager.

Nevertheless, Mudrack (2006) raises a doubt over this factor being representative in the triad being studied here, commenting that its presence or absence are not a necessary condition to categorize an 
individual as a workaholic.

In light of the above, we propose the following hypothesis:

H6. An entrepreneur's lack of work enjoyment has a positive effect on his intention to quit.

\subsection{Mediating effects}

Highly driven individuals feel an irresistible force pushing them to work in a compulsive manner, thus achieving a high work involvement (Bakker et al., 2008; Bonebright et al., 2000; Schaufeli et al., 2008)

Meanwhile, an excessive work charge (work involvement) creates a situation of psychological discomfort and alters how the individual perceives stress, not only affecting the social environment, working enjoyment and performance, but also altering the outside of work environment (Porter, 1996; Salanova et al., 2008).

Therefore, we predict that the work involvement of an entrepreneur will mediate the effect of driveness on the lack of work enjoyment.

H7. An entrepreneur's work involvement mediates the effect of his driveness on his lack of work enjoyment.

Workaholics have an obsession towards work, coming from an inner compulsion (driveness) or need to work they cannot resist (Clark et al., 2016; Oates, 1971), which derives from high work involvement.

As a result, according to Porter (1996), from a company's standpoint, when individuals present excessive work patterns, showing high work involvement, the possibility of burnout increases, as well as the turnover rates. In this way, higher work involvement leads to an increased propensity to quit work.

As such, we propose that work involvement will mediate the impact of driveness on the intention to quit:

H8. An entrepreneur's work involvement mediates the effect of his driveness on his intention to quit.

The driveness to work makes the workaholic feel guilty when not working, reducing life satisfaction (Clark et al., 2016). This same driveness makes the workaholic less able to recover from work stress due to the continuous pressure they put on themselves to work, even relating workaholism to poor mental health (van Wijhe et al., 2013). In studies on burnout, this constant pressure is related to emotional exhaustion, often considered a component of burnout (Moyer et al., 2017). As a whole, these effects of driveness can contribute to a lack of well-being and work enjoyment.

At the same time, a high work involvement, evidenced by excessive working hours, presents negative consequences to the individual such as increased stress levels, a decline in performance and an increase in work-related health issues and accidents, all contributing to lowering work enjoyment (Porter, 1996; Salanova et al., 2008).

Meanwhile, Kanai and Wakabayashi (2004), in their study of the effects of the Japanese crisis of 1991 over workaholism, propose work enjoyment as an element capable of strengthening the effect of the remaining aspects causing workaholism.

Under this theory by Kanai and Wakabayashi (2004), with high and constant driveness and work involvement, a decrease in work enjoyment, such as the one generated by the economic crisis in 1991 studied by the authors, will strengthen the total effect over workaholism and, consequently, the intention to quit. Therefore, driveness and work involvement should affect the intention to quit through the mediation of work enjoyment.

Thus, the following mediating hypotheses are provided:

H9. An entrepreneur's lack of work enjoyment mediates the effect of his driveness on his intention to quit.

H10. An entrepreneur's lack of work enjoyment mediates the effect of his work involvement on his intention to quit.
Bonebright et al. (2000) define the excessive work shown by workaholics (work involvement) as an uncontrollable urge to work (driveness), even though no, or very little, satisfaction is obtained.

This high work involvement will then cause heightened stress and discomfort, while altering the work enjoyment and social environment (Porter, 1996; Salanova et al., 2008).

Finally, as Kanai and Wakabayashi (2004) explain, this lack of work enjoyment will strengthen the effect of work involvement on the intention to quit. This way, we propose that work involvement and work enjoyment should mediate the effect of driveness on the intention to quit.

H11. An entrepreneur's work involvement and lack of work enjoyment mediate the effect of his driveness on his intention to quit.

\section{Methodology and model proposal}

\subsection{Sample and process}

In order to apply the concept of new company, and according to Reynolds et al. (2005), the present study considers a company as newly created when it is between three and 42 months of age. To determine the total population, the SABI database (Bureau Van Dijk - financial company information and business intelligence for companies in Spain and Portugal) was consulted, obtaining a total of 909 SMEs. The fact that only companies located in tourist destination municipalities in Gran Canaria were considered, ensured that all of them worked under the same economic and tax framework. The total number of surveyed entrepreneurs was 231, which represents a sample error of $5,6 \%$. The selection of these companies was randomly made. Surveys were personally conducted by surveyors who moved to the location of the companies. In all cases, the respondent was both the founder and manager of the company. Among the respondent population, $52 \%$ were men and $48 \%$ women. Moreover, it should be noted that $28 \%$ of the respondents had never before created a company and 31\% had a university certification.

\subsection{Measurement}

For this research, the method used to obtain the data necessary to fulfill its objectives was a survey, of which the basic observation instrument was a questionnaire (Sierra Bravo, 1991).

In order to evaluate the intention to quit the entrepreneurial activity, an adaptation of part of the questionnaire proposed by Liñán and Chen (2009) was used, specifically the part evaluating the intention to become an entrepreneur. On the other hand, according to MorenoJiménez et al. (2005), the main instruments used to measure work addiction are: a. The Workaholic Adjective Checklist (Haymon, 1993), consisting of 72 items related to five factors (anxiety, obsessive compulsive, mania, intolerance and self-doubt), b. The Work Addiction Risk Test (Robinson, 1999), composed of 25 items compiled into five dimensions (compulsive tendencies, control, self-absorption/impaired communication, inability to delegate and self-worth), and c. The Workaholism Battery (Spence and Robbins, 1992), using 25 items encompassed in three dimensions (driveness to work, work involvement and work enjoyment). In this research, the workaholism inventory was used, that is, the Work Addiction Risk Test (WART) (Robinson, 1999).

In order to determine the work addiction dimensions applied in this research, factor analysis was performed for every item in the WART scale (Robinson, 1999). From this analysis, four factors were obtained, of which one, consisting of only one item, represented a very low proportion of the variance. The remaining three factors contained variables corresponding to the three constructs proposed by Spence and Robbins (1992), driveness, work involvement and work enjoyment, so these factors were used.

The questionnaire was pre-tested with seven entrepreneurs which 
allowed them to point out what questions they could not understand or thought could lead to confusion. After the pre-test was completed, several questions were reworded to make their understanding easier by those completing the questionnaire.

\section{Data analysis}

With the field work's conclusion, the obtained data set was coded and tabulated. For this, the statistical program SPSS (Statistical Package for Social Sciences) for Windows version 25 was used. Covariancebased structural equation analysis was also used to study the data. The $\mathrm{R}$ Lavaan package was used for this purpose (Rosseel, 2012).

An important problem to solve in this kind of research is common method variance. Regarding this, in order to reduce the existence of this problem, questions were written introducing semantic differences, in addition to writing and coding some questions in negative form (Podsakoff et al., 2003). On the other hand, various empirical procedures were used in the present work in order to determine if the common method variance problem could compromise the interpretation of the obtained results. Using the work of Martinez-Martinez et al. (2019), the following procedures were employed: Harman's single factor test and the confirmatory factor-analytic approach to the Harman single factor test.

Regarding Harman's single factor test and, as suggested by Podsakoff and Organ (1986), the items related to both the independent and dependent variable were included in the factor analysis. Factors found with an eigen value above 1 explain a variance between $4,9 \%$ (the lowest) and 15,3\% (the highest), adding up to a total explained variance of 66.83. Since none of the factors individually explains over $50 \%$, the data can be accepted as valid with no existence, according to the test, of common method bias (Podsakoff and Organ, 1986).

Next, as a more sophisticated evaluation, the confirmatory factoranalytic approach to the Harman single-factor test was applied (Chang et al., 2010). The one-factor model yielded a Satorra-Bentler $\chi 2$ $(324)=2155.067 ; \quad \chi 2 /$ d.f $=6.651 ; \quad$ CFI $=0.499 ; \quad$ RMSEA $=0.177$, compared with the Satorra-Bentler $\chi^{2} \quad(318)=558.913 ; \chi^{2}$ / d.f $=1.757$; $C F I=0.935$; RMSEA $=0.064$ ). According to MartinezMartinez et al. (2019), a worse single-factor model fit suggests that the common method bias does not compromise the interpretation of the results.

In order to examine the causal relation between the constructs, a two-stage procedure was followed, as suggested by Hair et al. (2010); Leong et al. (2013) and Wang et al. (2014). The first stage consists of an exploratory factor analysis of utility to refine and determine the dimensional character of the scale (Cabrera-Suárez et al., 2014). The second stage is a confirmatory factor analysis to evaluate the validity of the constructs (Chan and Chong, 2012; So et al., 2013).

To evaluate the convergent validity, the estimated load for every indicator was examined in its corresponding construct. For said validity to exist, the load should be high and the t-values statistically significant (Anderson and Gerbing, 1988). In the proposed model, this is confirmed, thus achieving an acceptable convergent validity. Therefore, the results of the confirmatory factor analysis show that the relation between every item and its corresponding construct is statistically significant, with loads that in almost every case are over 0.7 (all p-values $\leq 0.001$ ), which implies the existence of convergent validity (see Table 1). Only one of the items, belonging to the construct "Work involvement," had a lower value, 0.652 to be exact. Since it remains a high value, the model was kept.

Moreover, it is necessary to determine the convergent validity of the constructs. According to Hair et al. (2016) and Roldán and SánchezFranco (2012), this validity must be checked using Cronbach's alpha test, Fornell and Larcker's composite reliability index (Fornell and Larcker, 1981) and the average variance extracted (AVE). For the first two cases, the point of reference is 0.7 , and for the third it's 0.5 (Hair et al., 2016; Roldán and Sánchez-Franco, 2012). In the model of study, as seen in Table 2, all these criteria are met. This way, the minimum value obtained on the Cronbach's alpha test is 0.872 , the composite reliability is 0.874 and AVE is 0.536 . Therefore, we can conclude that the reflexive constructs are reliable. To measure the discriminant validity, the square root of AVE (located in the diagonal of the matrix in Table 2) was compared to correlations between the constructs (the elements located outside the diagonal) (Chin, 1998; Roldán and Sánchez-Franco, 2012). We can observe that, on average, every construct relates more strongly with its own medium than with other constructs. In addition, a chi-squared test was performed (Zait \& Bertea, 2011), showing all our constructs were significantly different. Furthermore, the evaluation of the Heterotrait-Monotrait Ratio of Correlations (HTMT) was used (Henseler et al., 2015). This criterion is stricter than the others. This measure establishes the proportion of heterotrait-monotrait correlations, with confirmed discriminant validity when values are under 0.90 (Hair et al., 2016). The highest obtained value in our sample is 0.631 , so there are no discriminant validity problems.

\subsection{Test of the hypotheses}

Before analyzing the proposed hypotheses, the structural model was verified with some accuracy of fit measures. Thus, we used robust maximum likelihood estimators to fit the measurement model (Satorra and Bentler, 2001; Satorra, 2003). As seen in Table 3, they all passed the recommended thresholds $(\mathrm{CFI}=0.940$; $\mathrm{TLI}=0.929$; $\mathrm{RMSEA}=$ 0.056; SRMR $=0.044$ ). Thus, we can confirm that the fit of the structural model is adequate.

On the path analysis, the importance of a path is determined based on its p-value. Results show that the $24.4 \%$ of the intent to quit variance is explained by the variables of the model. In addition, the $\mathrm{R}^{2}$ of the excess of work is $34,7 \%$ and, in the case of the lack of enjoyment, it's 44,2\%. Furthermore, as seen in Fig. 1 and Table 4, all the hypotheses proposing direct relations are supported, except for the one relating driveness with the intention to quit. Thus, the following hypotheses are accepted: 1. the lack of enjoyment of the entrepreneur has a positive effect on the intention to abandon the entrepreneurial activity $(\beta=0.558, p<0.001) ; 2$. The work involvement $(\beta=0.208$, $\mathrm{p}=0.030)$ and the driveness $(\beta=0.521, \mathrm{p}<0.001)$ have a positive relation with the lack of work enjoyment of the entrepreneur; 3 . Driveness of the entrepreneur has a positive relationship with work involvement $(\beta=0.589, \mathrm{p}<0.001) ; 4$. The hypothesis directly relating driveness $(\beta=-0.047, \mathrm{p}=0.647)$ and work involvement $(\beta=$ $-0.089, p=0.299$ ) with the intention to quit cannot be accepted. It should be noted that, in addition to evaluating the $\mathrm{Z}$-value, a percentile bootstrap at $95 \%$ confidence interval (5000 re-samples) was made, obtaining the same results over the relationships.

To test the mediation hypotheses, bootstrapping procedure was applied (using 5000 re-samples) to determine at $95 \%$ the confidence intervals with corrected bias around these effects (Hille et al., 2015). As shown in Table 5, these hypotheses are supported:

a The hypothesis considering that work involvement has a mediating effect between driveness and the lack of work enjoyment ( $\beta=0.122, p=0.049,[0.022 ; 0.307])$. It should be noted that the direct effect was already significant, so it's a partial mediation.

b The hypothesis stating the lack of work enjoyment has a mediating effect between work involvement and driveness $(\beta=0.116$, $\mathrm{p}=0.040$, [0.028;0.379]). In this case, the direct effect between work involvement and the intention to quit was not significant, so we can affirm the mediation is total. Nevertheless, it must be taken into account that the total effect is not significant.

c The hypothesis placing the lack of entrepreneur work enjoyment as a mediating variable between driveness and the intention to quit entrepreneurship ( $\beta=0.291, p=0.002$, [0.186;0.689]). This must be considered as a complete mediation since the direct effect 
Table 1

Confirmatory analyses.

\begin{tabular}{|c|c|c|c|}
\hline Construct/Indicator & Standardized loading & Z- Value & p-value \\
\hline \multicolumn{4}{|l|}{ Work involvement* } \\
\hline I prefer to do most things myself rather than ask for help. & 0.752 & & \\
\hline I get impatient when I have to wait for someone else or when something takes too long, such as long, slow-moving lines. & 0.781 & 11.672 & $\leq 0.001$ \\
\hline I seem to be in a hurry and racing against the clock. & 0.790 & 11.822 & $\leq 0.001$ \\
\hline I get irritated when I am interrupted while in the middle of something. & 0.652 & 9.641 & $\leq 0.001$ \\
\hline I stay busy and keep many irons in the fire. & 0.722 & 10.743 & $\leq 0.001$ \\
\hline I overly commit myself by biting off more than I can chew. & 0.702 & 10.421 & $\leq 0.001$ \\
\hline \multicolumn{4}{|l|}{ Lack of work enjoyment* } \\
\hline I feel guilty when I am not working on something. & 0.751 & & \\
\hline It is important that I see the concrete results of what I do. & 0.705 & 10.540 & $\leq 0.001$ \\
\hline I am more interested in the final result of my work than in the process. & 0.736 & 11.025 & $\leq 0.001$ \\
\hline Things do not seem to move fast enough or get done fast enough for me. & 0.825 & 12.442 & $\leq 0.001$ \\
\hline I lose my temper when things don't go my way or work out to suit me. & 0.798 & 12.034 & $\leq 0.001$ \\
\hline \multicolumn{4}{|l|}{ Intention to quit $* *$} \\
\hline My objective is to stop being an entrepreneur in the short-term. & 0.922 & & \\
\hline I have seriously considered to stop being an entrepreneur. & 0.901 & 23.267 & $\leq 0.001$ \\
\hline I have the firm intention to stop being an entrepreneur. & 0.951 & 27.891 & $\leq 0.001$ \\
\hline I am willing to do anything needed to stop being an entrepreneur. & 0.959 & 28.731 & $\leq 0.001$ \\
\hline I will do an effort to be able to abandon the entrepreneurship as soon as possible. & 0.911 & 24.074 & $\leq 0.001$ \\
\hline \multicolumn{4}{|l|}{ Driveness* } \\
\hline I spend a lot of time mentally planning and thinking about future events while tuning out the here and now. & 0.743 & & \\
\hline I find myself continuing to work after my coworkers have called it quits. & 0.773 & 11.964 & $\leq 0.001$ \\
\hline I get angry when people don't meet my standards of perfection. & 0.754 & 11.636 & $\leq 0.001$ \\
\hline I get upset when I am in situations where I cannot be in control. & 0.736 & 11.339 & $\leq 0.001$ \\
\hline I put myself under pressure with self-imposed deadlines when I work. & 0.787 & 12.209 & $\leq 0.001$ \\
\hline It is hard for me to relax when I am not working. & 0.707 & 10.843 & $\leq 0.001$ \\
\hline I spend more time working than on socializing with friends, on hobbies, or on leisure activities. & 0.702 & 10.759 & $\leq 0.001$ \\
\hline I dive into projects to get a head start before all phases have been finalized. & 0.758 & 11.707 & $\leq 0.001$ \\
\hline I get upset with myself for making even the smallest mistake. & 0.751 & 11.596 & $\leq 0.001$ \\
\hline I put more thought, time and energy into my work than I do into my relationships with friends or loved ones. & 0.787 & 12.199 & $\leq 0.001$ \\
\hline I forget, ignore, or minimize birthdays, reunions, anniversaries, or holidays. & 0.735 & 11.324 & $\leq 0.001$ \\
\hline
\end{tabular}

Note: *Adapted from Robinson (1999); **Adapted from Liñán and Chen (2009).

Table 2

Reliability, convergent validity and discriminant validity: correlation coefficients and Chi-square difference test.

\begin{tabular}{|c|c|c|c|c|c|c|c|}
\hline Cronbach's alpha & Composite reliability & AVE & Construct & Driveness & Work involvement & Lack of work enjoyment & Intention to quit \\
\hline 0.932 & 0.933 & 0.559 & Driveness & 0.748 & & & \\
\hline 0.872 & 0.874 & 0.536 & Work involvement & $\begin{array}{l}0.589 * * * \\
\left(76.065^{* * *}\right) \\
\# 0.606 \#\end{array}$ & 0.732 & & \\
\hline 0.875 & 0.875 & 0.585 & Lack of work enjoyment & $\begin{array}{l}0.643^{* * *} \\
\left(93.752^{* * *}\right) \\
\# 0.631 \#\end{array}$ & $\begin{array}{l}0.514 * * * \\
(51.362 * * *) \\
\# 0.521 \#\end{array}$ & 0.765 & \\
\hline 0.969 & 0.969 & 0.863 & Intention to quit & $\begin{array}{l}0.260^{* * *} \\
\left(14.57^{* * *}\right) \\
\# 0.264 \#\end{array}$ & $\begin{array}{l}0.171^{*} \\
\left(5.653^{*}\right) \\
\# 0.189 \#\end{array}$ & $\begin{array}{l}0.483^{* * *} \\
(50.526 * * *) \\
\# 0.469 \#\end{array}$ & 0.929 \\
\hline
\end{tabular}

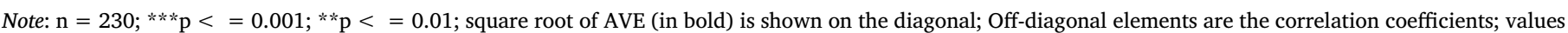
in brackets show the chi-square difference statistics with $\mathrm{df}=1$; values in \# show the ratio of heterotrait-monotrait correlations.

between driveness and the intention to quit was not significant.

On the other hand, the hypothesis placing work involvement mediating between driveness and the intention to quit was not supported.

Regarding the existence of multiple mediation, with two mediating variables, work involvement and the lack of work enjoyment, between driveness and the intention to quit, although not supported according to the p-value (0.063), the bootstrap test does show the result as significant. Despite this, the effect is quite small.

\section{Conclusions, limitations and future lines of research}

Becoming an entrepreneur is a tough task, full of obstacles, which in many cases are faced alone or with the help of only a few people. For this reason, entrepreneurs are persistent by nature and have low risk aversion (Kan and Tsai, 2006; Kihlstrom and Laffont, 1979). Compared to the general population, entrepreneurs are considered to have a higher risk propensity (Block et al., 2015; Herranz et al., 2015), which helps them traverse the bridge between opportunity recognition and the business venture (Lago et al., 2018). These psychological features may push entrepreneurs to show high work dedication (Barrick and Mount, 1991; Zhao and Seibert, 2006) in order to make their company succeed in an uncertain environment. In addition, the division between company and entrepreneur is sometimes indistinguishable (Brüderl and Preisendörfer, 1998; Chandler and Jansen, 1992), accentuating any problems.

Moreover, when future entrepreneurs receive training, hard work, persistence and low risk aversion are usually perceived as essential personal characteristics, which intensifies the problem of entrepreneurs working to excess.

The tourism sector is one of the world's principal industries and, in the case of many countries, a crucial asset in their economy, an important job generator and a development driver (WEF, 2018). On the other hand, nowadays, almost noone doubts the role of 
Table 3

Measures of the model fit.

\begin{tabular}{lll}
\hline Number of observations 230 & & \\
\hline Estimator & $\begin{array}{l}\text { Maximum } \\
\text { likelihood }\end{array}$ & Robust \\
\hline Minimum Function Test Statistic & 704.437 & 558.913 \\
Degrees of freedom & 318 & 318 \\
P-value (Chi-square) & $\leq 0.001$ & $\leq 0.001$ \\
Scaling correction factor or the Satorra-Bentler & & 1.260 \\
$\quad$ correction & & \\
Model test baseline model & & 4455.870 \\
Minimum Function Test Statistic & 5058.206 & 351 \\
Degrees of freedom & 351 & $\leq 0.001$ \\
P-value & $\leq 0.001$ & Robust \\
& Maximum & \\
User model versus baseline model $_{\text {Comparative Fit Index (CFI) }}^{\mathrm{a}}$ & likelihood & \\
Tucker-Lewis Index (TLI) & & 0.935 \\
RMSEA $^{\mathrm{b}}$ & 0.918 & 0.928 \\
SRMR $^{\mathrm{d}}$ & 0.909 & 0.064 \\
\hline
\end{tabular}

a Recommended value $>=0.90$ [53].

b Recommended value $>=0.90$ [53].

c Recommended value $<=0.08$ [54].

d Recommended value $<=0.1$ [54].

entrepreneurship as a tool capable of generating jobs and development in the regions. The great importance of SMEs in this sector is no novelty either. Moreover, the central role the entrepreneur plays in the initial stages of a business should be highlighted, especially for SMEs. Thus, entrepreneurs must make a great personal and material effort for their companies to achieve success. In the initial stages of businesses, entrepreneurs invest not only their money, but also a large number of work hours and personal sacrifice. Evidently, this can drive them to workaholism, which can end up damaging their health, indirectly harming the performance of their business.

This article aims to make a contribution to the literature on entrepreneurship in the tourism sector by analyzing psychological factors of the entrepreneur as a source of failure in the enterprise initiative. This is done through the study of the relationship between the different constructs which, according to Spence and Robins (1992), form work addiction, and the intention to quit. In this way, this article sheds light on the determinants of failure in an activity, entrepreneurship, that is highly relevant in the tourism sector. Based on the literature review, this article is the first study of this relationship.
Centering attention on the proposed hypotheses, it should be noted that all those related to a direct relationship have been accepted, except for those linking driveness and work involvement with the intention to quit. These results are consistent with those of Burke and MacDermid (1999).

Nevertheless, when counting the indirect effects, the total effect of driveness over the intention to quit is significant. Thus, one of the most important results of this research is the acceptance of the lack of work enjoyment variable totally mediating the relationship between driveness and the intention to quit entrepreneurship. In line with Kanai and Wakabayashi (2004), we have found that work enjoyment can act as a mediator, strengthening the effect of the driveness to work on the intention to quit.

Therefore, the existence of a link between entrepreneur driveness, work involvement and, in addition, the lack of work enjoyment is proven. This result aligns with the postulates of Schaufeli et al. (2008).

On the other hand, it should be noted that the fact that the relation between work involvement and the intention to quit entrepreneurship is not supported can be attributed to an important part of the entrepreneur work involvement coming from other factors such as the engagement of the individual with the company (Schaufeli et al., 2008).

A way to combat workaholism and mediate its effects could be the enhancement of certain intangible assets of the firm. It should be highlighted that intangible resources are important determinants of business competitiveness (Hormiga et al., 2011a; Teece, 2000). In the case of new businesses, Lichtenstein and Brush (2001) report intangible assets to be even more important than their tangible counterparts. Intellectual capital is generally divided into three categories: human capital, structural capital and relational capital (Bødker and Andersen, 2005; Hormiga et al., 2011b; Marr and Roos, 2005; Sánchez-Medina et al., 2007; Sydler et al., 2014). Below we offer examples of how an asset from each of these categories may help reduce this problem.

First, as an example of how human capital may help with workaholism, proper training could be a key to preventing workaholism. Entrepreneur training programs, one of the ways in which the public sector intervenes in entrepreneurship (Butler et al., 2016), typically center on financial and enterprise management. However, knowing the relationship between the constructs forming workaholism and the intention to abandon entrepreneurship in the tourism sector, training could be designed to aid entrepreneurs, real or potential, face the effects of workaholism, and make them aware of its impact on enterprise failure.

Second, an intangible asset from the structural capital category which may help alleviate the effects of workaholism is, for example, planning. On this matter, Van Zyl and Lotz (2008) explain that most

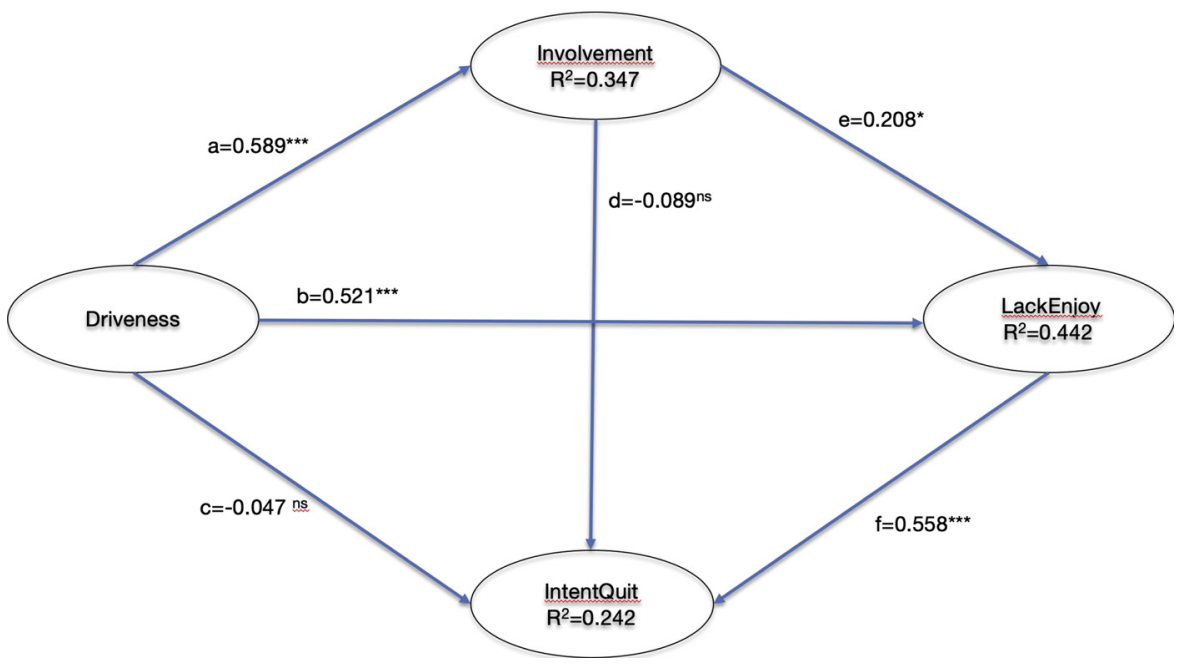

Fig. 1. Structural model. 
Table 4

Results of path analysis.

\begin{tabular}{|c|c|c|c|c|c|c|}
\hline Direct Effect & Estimate & Standard error & Z-value & p-Value & $\begin{array}{l}\text { Percentile Bootstrap } \\
95 \% \text { confidence interval }\end{array}$ & Remarks \\
\hline $\begin{array}{l}\text { Driveness } \rightarrow \\
\quad \text { Work involvement (a) }\end{array}$ & $0.589 * * *$ & 0.073 & 7.106 & $\leq 0.001$ & [0.377; 0.664]Sig & Supported \\
\hline $\begin{array}{l}\text { Work involvement } \rightarrow \\
\quad \text { Lack of work enjoyment (e) }\end{array}$ & $0.208^{*}$ & 0.127 & 2.172 & 0.030 & {$[0.027 ; 0.526]$ Sig } & Supported \\
\hline $\begin{array}{l}\text { Driveness } \rightarrow \\
\quad \text { Lack of work enjoyment (b) }\end{array}$ & $0.521^{* * *}$ & 0.135 & 4.538 & $\leq 0.001$ & {$[0.348 ; 0.877] \mathrm{Sig}$} & Supported \\
\hline $\begin{array}{l}\text { Driveness } \rightarrow \\
\quad \text { Intention to quit (c) }\end{array}$ & $-0.047^{\mathrm{ns}}$ & 0.153 & 0.421 & 0.647 & {$[-0.365 ; 0.236]$ NoSig } & Not Supported \\
\hline $\begin{array}{l}\text { Work involvement } \rightarrow \\
\quad \text { Intention to quit (d) }\end{array}$ & $-0.089^{\text {ns }}$ & 0.133 & 1.039 & 0.299 & {$[-0.400 ; 0.123] \mathrm{NoSig}$} & Not Supported \\
\hline $\begin{array}{c}\text { Lack of work enjoyment } \rightarrow \\
\text { Intention to quit (f) }\end{array}$ & $0.558^{* * *}$ & 0.129 & 5.097 & $\leq 0.001$ & {$[0.404 ; 0.908]$ Sig } & Supported \\
\hline
\end{tabular}

Significance level: ${ }^{* * *} \mathrm{p}<0.001 ;{ }^{* *} \mathrm{p}<0.01 ; * \mathrm{p}<0.05 ;{ }^{\mathrm{ns}}$ not significant.

Sig: Significant; NoSig: not significant.

entrepreneurs don't plan a business exit, ignoring it until a crisis or an unexpected event makes it imminent. Having a planned exit reduces the uncertainties and, consequently, the pressure over the entrepreneur. Moreover, planning the withdrawal from an economic activity increases the chance of a successful exit.

Third, in the case of relational capital, cooperation with competitors, commonly called coopetition, may help reduce or prevent workaholism. In this sense, coopetition between agents in one sector allows for a generalized increase in competitive advantage or even the creation of an inimitable advantage (Cortese et al., 2018), which will generally translate into greater success and better efficiency of the companies in this sector, reducing the need to work long hours. Since success and rewards are commonly related to an increase in work enjoyment (Locke and Latham, 1990; Wrzesniewski et al., 1997), this coopetition could serve as a way to combat the lack of work enjoyment, one of the factors causing workaholism according to Spence and Robbins (1992).

Regarding the theoretical implications, in essence, our results demonstrate that the relationship between workaholism and the intention to quit entrepreneurship in the tourist SME sector is supported. This makes a contribution to the research field of entrepreneur exit. As highlighted by DeTienne and Wennberg (2016), the factors explaining why an entrepreneur might leave successful ventures remain a research field where we have limited understanding.

Following the recommendation of Kallmuenzer and Peters (2018), this study has shed some light over the effect of firms' entrepreneurial characteristics and motivations as decisive factors for business failure. Through the identification of workaholism, a psychological characteristic of the entrepreneur, as a key aspect for business failure, the importance of the study of the tourism entrepreneur's personality and psychological characteristics have been further corroborated.
Thus, workaholism should be placed among other psychological factors considered to have an effect on entrepreneur failure such as the lack of confidence and risk-aversion, which are considered to inhibit entrepreneurial behavior, acting as barriers to entrepreneurship (Asiedu and Nduro, 2015; Cacciotti et al., 2016).

On the other hand, the most relevant practical implication lies in entrepreneurs and the institutions promoting entrepreneurship in different regions. This is important, because if entrepreneurs are aware of this relationship, they can try to establish mechanisms to prevent or mediate workaholism.

First, the knowledge of the effects of workaholism on entrepreneurship can help entrepreneurs prevent such issues by self-assessing and, if needed, seeking professional help. By making entrepreneurs conscious of the relationship between workaholism and entrepreneurial exit, we can reduce the number of cases of failed entrepreneurship. In this way, the whole economy benefits from this study.

Second, entrepreneur performance is sensitive to the institutional context (Estrin et al., 2016). However, the public sector's intervention into entrepreneurship typically centers on upgrading institutions, reducing financial frictions and barriers to the entrepreneur, and enhancing entrepreneurship, generally through programs aimed at enterprise promotion (Butler et al., 2016). Knowing the impact of workaholism on entrepreneur exit, private sector intervention should cover exit strategic planning, contributing to a greater chance of success in a business exit.

In addition, a continuation of this line of work on the relationship between workaholism and entrepreneur exit, further integrating other disciplines like sociology and psychology, will give better insight on workaholism as a whole, potentially creating better tools and practices to prevent, identify and treat workaholism.

Table 5

Mediation analysis.

\begin{tabular}{|c|c|c|c|c|c|}
\hline Indirect Effect & Estimate & Std. Error & Z-value & p-Value & $\begin{array}{l}\text { Percentile Bootstrap } \\
95 \% \text { confidence interval }\end{array}$ \\
\hline$a * e$ & $0.122^{*}$ & 0.073 & 1.970 & 0.049 & {$[0.022 ; 0.307] \mathrm{Sig}$} \\
\hline$e^{* f} f$ & $0.116^{*}$ & 0.088 & 2.049 & 0.040 & {$[0.028 ; 0.379] \mathrm{Sig}$} \\
\hline$b * f$ & $0.291^{* *}$ & 0.127 & 3.154 & 0.002 & {$[0.186 ; 0.689] \mathrm{Sig}$} \\
\hline$a * d$ & $-0.052^{\mathrm{ns}}$ & 0.073 & 0.993 & 0.321 & {$[-0.212 ; 0.075]$ NoSig } \\
\hline$a^{*} e^{* f}$ & $0.068^{\mathrm{ns}}$ & 0.051 & 1.857 & 0.063 & {$[0.014 ; 0.207] \mathrm{Sig}$} \\
\hline Total Effect & Estimate & Std. Error & Z-value & p-Value & $\begin{array}{l}\text { Percentile Bootstrap } \\
95 \% \text { confidence interval }\end{array}$ \\
\hline Driveness - > Intention to quit & $0.260 * *$ & 0.116 & 3.096 & 0.002 & {$[0.134 ; 0.590] \mathrm{Sig}$} \\
\hline Work involvement $->$ Intention to quit & $0.027^{\mathrm{ns}}$ & 0.150 & 0.284 & 0.777 & {$[-0.239 ; 0.351]$ NoSig } \\
\hline Driveness - > Lack of work enjoyment & $0.643^{* * *}$ & 0.115 & 6.574 & $\leq 0.001$ & {$[0.546 ; 0.999] \mathrm{Sig}$} \\
\hline
\end{tabular}

Significance level: ${ }^{* * *} \mathrm{p}<0.001 ; * * \mathrm{p}<0.01 ; * \mathrm{p}<0.05$; ${ }^{\text {ns }}$ not significant.

Sig: Significant; NoSig: not significant. 
Regarding the limitations of the present work, it should be noted that a transversal methodology was used, thus increasing the chance of the study containing bias due to the use of only one method/data source. In addition, this study is limited by centering on one economic sector, working in one specific tourism destination.

Regarding future lines of investigation, we consider the main line should try to include other factors in this model, both internal and external to the company, that can increase or moderate workaholism on entrepreneurs. Also, regarding the population of the study, it would be interesting to expand to different tourism destinations, sectors and even company sizes (this study focused on SMEs). This would allow for comparison, identifying different trends derived from cultural differences, for example.

As stated by Bredvold and Skålén (2016); Morrison (2006) and Thomas et al. (2011), the tourism entrepreneur is generally considered a lifestyle entrepreneur. This is because of a divergence from the traditional entrepreneur in terms of goals, decision-making and risk-taking (Bredvold and Skålén, 2016). Based on this specific nature of the tourism entrepreneur, it would be interesting to study this phenomenon in smaller sections of the tourism industry. For example, Crawford and Naar (2016) found Bed \& Breakfast entrepreneurs to be more conscious about their business exit and even show a better planning of the exit, which drove them to consider Bed \& Breakfast entrepreneurship as a transition to retirement.

In addition, an interesting line of research which should be further developed is the study of various entrepreneur profiles, continuing research on the experiences of entrepreneurs (DeTienne and Cardon, 2012; Lee and Lee, 2015; Wennberg et al., 2010), covering aspects such as work experience, education, industry or previous entrepreneurship experience. This way, by segmenting the results of research like this under these experience variables, a more complete knowledge of the exact factors leading to tourism entrepreneur withdrawal could be attained.

Finally, it would be beneficial to conduct research on motivating behavior among entrepreneurs relative to workaholism to see if it differs between those who have created their company because they felt a calling or out of necessity.

\section{Declaration of Competing Interest}

None.

\section{References}

Acs, Z.J., Szerb, L., 2007. Entrepreneurship, economic growth and public policy. Small Bus. Econ. 28 (2-3), 109-122.

Acs, Z.J., Desai, S., Hessels, J., 2008. Entrepreneurship, economic development and institutions. Small Bus. Econ. 31 (3), 219-234.

Acs, Z.J., Estrin, S., Mickiewicz, T., Szerb, L., 2018. Entrepreneurship, institutional economics, and economic growth: an ecosystem perspective. Small Bus. Econ. 51 (2), 501-514.

Ahmad, S.Z., 2015. Entrepreneurship in the small and medium-sized hotel sector. Curr. Issues Tour. 18 (4), 328-349.

Ajzen, I., 1991. The theory of planned behaviour. Organ. Behav. Hum. Decis. Process. 40 (2), 179-211.

Amorós, J.E., Cristi, O., 2008. Longitudinal analysis of entrepreneurship and competitiveness dynamics in Latin America. Int. Entrep. Manag. J. 4 (4), 381-399.

Anderson, J.C., Gerbing, D.W., 1988. Structural equation modeling in practice: a review and recommended two-step approach. Psychol. Bull. 103 (3), 411-423.

Arshi, T., Burns, P., 2018. Entrepreneurial architecture: a framework to promote innovation in large firms. J. Entrep. 27 (2), 151-179.

Artz, B., 2017. Gender and entrepreneurial success: evidence from survey data. Appl. Econ. Lett. 24 (3), 163-166.

Asiedu, M., Nduro, K., 2015. Polytechnic students' entrepreneurial knowledge, preferences and perceived barriers to start-up business. Eur. J. Bus. Manag. 7 (21), $20-28$.

Aziz, S., Zickar, M.J., 2006. A cluster analysis investigation of workaholism as a syndrome. J. Occup. Health Psychol. 11 (1), 52-62.

Bakker, A.B., Schaufeli, W.B., Leiter, M.P., Taris, T.W., 2008. Work engagement: an emerging concept in occupational health psychology. Work Stress 22 (3), 187-200.

Barrick, M.R., Mount, M.K., 1991. The Big five personality dimensions and job performance: a meta-analysis. Pers. Psychol. 44, 1-26.
Blackburn, R., Kovalainen, A., 2009. Researching small firms and entrepreneurship: past, present and future. Int. J. Manag. Rev. 11 (2), 127-148.

Block, J., Sandner, P., Spiegel, F., 2015. How do risk attitudes differ within the group of entrepreneurs? The role of motivation and procedural utility. J. Small Bus. Manag. 53 (1), 183-206.

Bødker, S., Andersen, P.B., 2005. Complex mediation. Hum. Interact. 20 (4), 353-402.

Bonebright, C.A., Clay, D.L., Ankenmann, R.D., 2000. The relationship of workaholism with work-life conflict, life satisfaction, and purpose in life. J. Couns. Psychol. 47 (4), $469-477$.

Bredvold, R., Skålén, P., 2016. Lifestyle entrepreneurs and their identity construction: a study of the tourism industry. Tour. Manag. 56, 96-105.

Breitenecker, R.J., Harms, R., Weyh, A., Maresch, D., Kraus, S., 2017. When the difference makes a difference-the regional embeddedness of entrepreneurship. Entrep. Reg. Dev. 29 (1-2), 71-93.

Brett, J.M., Stroh, L.K., 2003. Working 61 plus hours a week: why do managers do it? J. Appl. Psychol. 88 (1), 67-78.

Brüderl, J., Preisendörfer, P., 1998. Network support and the success of newly founded business. Small Bus. Econ. 10 (3), 213-225.

Brüderl, J., Preisendörfer, P., Ziegler, R., 1992. Survival chances of newly funded business organizations. Am. Sociol. Rev. 57 (2), 227-242.

Burke, R.J., 2000. Workaholism in organizations: concepts, results and future directions. Int. J. Manag. Rev. 2 (1), 1-16.

Burke, R.J., 2006. Research Companion to Working Time and Work Addiction. Edward Elgar Publishing, UK.

Burke, R.J., MacDermid, G., 1999. Are workaholics job satisfied and successful in their careers? Career Dev. Int. 4 (5), 277-282.

Busenitz, L.W., West, G.P., Shepherd, D., Nelson, T., Chandler, G.N., Zacharakis, A., 2003. Entrepreneurship research in emergence: past trends and future directions. J. Manage. 29 (3), 285-308.

Butler, I., Galassi, G., Ruffo, H., 2016. Public funding for startups in Argentina: an impact evaluation. Small Bus. Econ. 46 (2), 295-309.

Cabrera-Suárez, M.K., Déniz-Déniz, M.D.L.C., Martín-Santana, J.D., 2014. The setting of non-financial goals in the family firm: the influence of family climate and identification. J. Fam. Bus. Strategy 5 (3), 289-299.

Cacciotti, G., Hayton, J.C., Mitchell, J.R., Giazitzoglu, A., 2016. A reconceptualization of fear of failure in entrepreneurship. J. Bus. Ventur. 31 (3), 302-325.

Carmichael, B.A., Morrison, A., 2011. Tourism entrepreneurship research. Tour. Plan. Dev. 8 (2), 115-119.

Chan, F.T., Chong, A.Y., 2012. A SEM-neural network approach for understanding determinants of interorganizational system standard adoption and performances. Decis. Support Syst. 54 (1), 621-630.

Chandler, G.N., Jansen, E., 1992. The founder's self-assessed competence and venture performance. J. Bus. Ventur. 7 (3), 223-236.

Chang, S.J., Van Witteloostuijn, A., Eden, L., 2010. From the editors: common method variance in international business research. J. Int. Bus. Stud. 41, 178-184.

Cherrington, D.J., 1980. The Work Ethic. American Management Association, New York.

Chin, W.W., 1998. Issues and opinion on structural equation modeling. Mis Q. 22 (1), $7-15$.

Clark, M.A., Michel, J.S., Zhdanova, L., Pui, S.Y., Baltes, B.B., 2016. All work and no play? A meta-analytic examination of the correlates and outcomes of workaholism. J. Manage. 42 (7), 1836-1873.

Cortese, D., Giacosa, E., Cantino, V., 2018. Knowledge sharing for coopetition in tourist destinations: the difficult path to the network. Rev. Manag. Sci. 1-12.

Covin, J.G., Slevin, D.P., 1989. Strategic management of small firms in hostile and benign environments. Strateg. Manage. J. 10 (1), 75-87.

Crawford, A., Naar, J., 2016. Exit planning of lifestyle and profit-oriented entrepreneurs in bed and breakfasts. Int. J. Hosp. Tour. Adm. 17 (3), 260-285.

Cressy, R., 2006. Why do most firms die young? Small Bus. Econ. 26 (2), 103-116.

Daskalopoulou, I., Petrou, A., 2009. Urban tourism competitiveness: networks and the regional asset base. Urban Stud. 46 (4), 779-801.

Davidsson, P., Wiklund, J., 2001. Levels of analysis in entrepreneurship research: current research practice and suggestions for the future. Entrep. Theory Pract. 25 (4), 81-99.

Decker, R., Haltiwanger, J., Jarmin, R., Miranda, J., 2014. The role of entrepreneurship in US job creation and economic dynamism. J. Econ. Perspect. 28 (3), 3-24.

Del Líbano, M., Llorens, S., Salanova, M., Schaufeli, W., 2010. Validity of a brief workaholism scale. Psicothema 22 (1), 143-150.

DeTienne, D.R., Cardon, M.S., 2012. Impact of founder experience on exit intentions. Small Bus. Econ. 38 (4), 351-374.

DeTienne, D., Wennberg, K., 2016. Studying exit from entrepreneurship: new directions and insights. Int. Small Bus. J. 34 (2), 151-156.

Dewhurst, P., Horobin, H., 1998. Small business owners. In: Thomas, R. (Ed.), The Management of Small Tourism and Hospitality Firms. Cengage Learning EMEA, USA, pp. 19-38.

Di Domenico, M., Miller, G., 2012. Farming and tourism enterprise: experiential authenticity in the diversification of independent small-scale family farming. Tour. Manag. 33 (2), 285-294.

Estrin, S., Mickiewicz, T., Stephan, U., 2016. Human capital in social and commercial entrepreneurship. J. Bus. Ventur. 31 (4), 449-467.

Fayolle, A., Gailly, B., 2015. The impact of entrepreneurship education on entrepreneurial attitudes and intention: hysteresis and persistence. J. Small Bus. Manag. 53 (1), 75-93.

Ferreira, J.J., Fernandes, C.I., Kraus, S., 2019. Entrepreneurship research: mapping intellectual structures and research trends. Rev. Manag. Sci. 13 (1), 181-205.

Fornell, C., Larcker, D.F., 1981. Evaluating structural equation models with unobservable variables and measurement error: algebra and statistics. J. Mark. Res. 18 (1), 39-50.

Fu, H., Okumus, F., Wu, K., Köseoglu, M.A., 2019. The entrepreneurship research in 
hospitality and tourism. Int. J. Hosp. Manag. 78, 1-12.

Galindo, M.Á., Méndez, M.T., 2014. Entrepreneurship, economic growth, and innovation: are feedback effects at work? J. Bus. Res. 67 (5), 825-829.

Gartner, W.B., 2001. Is there an elephant in entrepreneurship? Blind assumptions in theory development. Entrep. Theory Pract. 25 (4), 21-39.

Goldberg, L.R., 1990. An alternative" description of personality": the big-five factor structure. J. Pers. Soc. Psychol. 59 (6), 1216-1229.

Gorgievski, M.J., Bakker, A.B., Schaufeli, W.B., 2010. Work engagement and workaholism: comparing the self-employed and salaried employees. J. Posit. Psychol. 5 (1), 83-96.

Gorgievski, M.J., Stephan, U., 2016. Advancing the psychology of entrepreneurship: a review of the psychological literature and an introduction. Appl. Psychol. 65 (3), 437-468.

Graves, L.M., Ruderman, M.N., Ohlott, P.J., Weber, T.J., 2012. Driven to work and enjoyment of work: effects on managers' outcomes. J. Manage. 38 (5), 1655-1680.

Hair, J.F., Black, W.C., Babin, B.J., Anderson, R.E., Tatham, R.L., 2010. Multivariate Data Analysis: A Global Perspective. Pearson Education, London.

Hair Jr , J.F., Hult, G.T.M., Ringle, C., Sarstedt, M., 2016. A Primer on Partial Least Squares Structural Equation Modeling (PLS-SEM). Sage publications, USA.

Hallak, R., Assaker, G., Lee, C., 2015. Tourism entrepreneurship performance: the effects of place identity, self-efficacy, and gender. J. Travel. Res. 54 (1), 36-51.

Harpaz, I., Snir, R., 2003. Workaholism: its definition and nature. Hum. Relat. 56 (3), 291-319.

Haymon, S., 1993. The Relationship of Work Addiction and Depression, Anxiety and Anger in College Males. Doctoral Dissertation. Florida State University, Dissertations Abstracts International.

Heinze, I., 2013. Entrepreneur sense-making of business failure. Small Enterp. Res. 20 (1), 21-39.

Henseler, J., Ringle, C.M., Sarstedt, M., 2015. A new criterion for assessing discriminant validity in variance-based structural equation modeling. J. Acad. Mark. Sci. 43 (1), 115-135.

Herranz, N., Krasa, S., Villamil, A.P., 2015. Entrepreneurs, risk aversion, and dynamic firms. J. Polit. Econ. 123 (5), 1133-1176.

Hille, P., Walsh, G., Cleveland, M., 2015. Consumer fear of online identity theft: scale development and validation. J. Interact. Mark. 30, 1-19.

Hormiga, E., Batista-Canino, R.M., Sánchez-Medina, A., 2011a. The impact of relational capital on the success of new business start-ups. J. Small Bus. Manag. 49 (4), 617-638.

Hormiga, E., Batista-Canino, R.M., Sánchez-Medina, A., 2011b. The role of intellectual capital in the success of new ventures. Int. Entrep. Manag. J. 7 (1), 71-92.

INE, Instituto Nacional de Estadística, 2015. Indicadores de Demografía Empresarial. Año 2015. INE, Madrid.

Jaafar, M., Abdul-Aziz, A.R., Maideen, S.A., Mohd, S.Z., 2011. Entrepreneurship in the tourism industry: issues in developing countries. Int. J. Hosp. Manag. 30 (4), 827-835.

Jans, N.A., 1982. The nature and measurement of work involvement. J. Occup. Psychol. 55 (1), 57-67.

Kallmuenzer, A., Peters, M., 2018. Entrepreneurial behaviour, firm size and financial performance: the case of rural tourism family firms. Tour. Recreat. Res. 43 (1), 2-14.

Kallmuenzer, A., Strobl, A., Peters, M., 2018. Tweaking the entrepreneurial orientation-performance relationship in family firms: the effect of control mechanisms and family-related goals. Rev. Manag. Sci. 12 (4), 855-883.

Kan, K., Tsai, W.D., 2006. Entrepreneurship and risk aversion. Small Bus. Econ. 26 (5), 465-474.

Kanai, A., Wakabayashi, M., 2004. Effects of economic environmental changes on job demands and workaholism in Japan. J. Organ. Chang. Manag. 17 (5), 537-548.

Kerr, S.P., Kerr, W.R., Xu, T., 2018. Personality traits of entrepreneurs: a review of recent literature. Found. Trends Entrepr. 14 (3), 279-356.

Kihlstrom, R.E., Laffont, J.J., 1979. A general equilibrium entrepreneurial theory of firm formation based on risk aversion. J. Polit. Econ. 87 (4), 719-748.

Killinger, B., 1991. Workaholics: The Respectable Addicts. Simon \& Schuster, New York.

Kolvereid, L., Isaksen, E., 2006. New business start-up and subsequent entry into selfemployment. J. Bus. Ventur. 21 (6), 866-885.

Korn, E.R., Pratt, G.J., Lambrou, P.T., 1987. Hyper-Performance: The A.I.M. Strategy for Releasing Your Business Potential. John Wiley, New York.

Köseoglu, M.A., Topaloglu, C., Parnell, J.A., Lester, D.L., 2013. Linkages among business strategy, uncertainty and performance in the hospitality industry: evidence from an emerging economy. Int. J. Hosp. Manag. 34, 81-91.

Lago, M., Delgado, C., Branco, M.C., 2018. Gender and propensity to risk in advanced countries. Psu Res. Rev. 2 (1), 24-34.

Lee, B., 2019. Human capital and labor: the effect of entrepreneur characteristics on venture success. Int. J. Entrepr. Behav. Res. 25 (1), 29-49.

Lee, S.M., Chang, D., Lim, S.B., 2005. Impact of entrepreneurship education: a comparative study of the US and Korea. Int. Entrep. Manag. J. 1 (1), 27-43.

Lee, S.M., Lee, B., 2015. Entrepreneur characteristics and the success of venture exit: an analysis of single-founder start-ups in the US. Int. Entrep. Manag. J. 11 (4), 891-905.

Leong, L.Y., Hew, T.S., Tan, G.W.H., Ooi, K.B., 2013. Predicting the determinants of the NFC-enabled mobile credit card acceptance: a neural networks approach. Expert Syst. Appl. 40 (14), 5604-5620.

Levasseur, L., Tang, J., Karami, M., 2019. Insomnia: an important antecedent impacting entrepreneurs' health. J. Risk Financ. Manag. 12 (1), 44.

Lichtenstein, B.M.B., Brush, C.G., 2001. How do "resource bundles" develop and change in new ventures? A dynamic model and longitudinal exploration. Entrep. Theory Pract. 25 (3), 37-58.

Liñán, F., Chen, Y., 2009. Development and cross-cultural application of a specific instrument to measure entrepreneurial intentions. Entrep. Theory Pract. 33 (3),
593-617.

Locke, E.A., Latham, G.P., 1990. Work motivation and satisfaction: light at the end of the tunnel. Psychol. Sci. 1 (4), 240-246.

Marr, B., Roos, G., 2005. A strategy perspective on intellectual capital. In: Marr, B. (Ed.), Perspectives on Intelectual Capital. Routledge, UK, pp. 28-52.

Martinez-Martinez, A., Cegarra-Navarro, J.G., Garcia-Perez, A., Wensley, A., 2019. Knowledge agents as drivers of environmental sustainability and business performance in the hospitality sector. Tour. Manag. 70, 381-389.

Mas-Tur, A., Pinazo, P., Tur-Porcar, A.M., Sánchez-Masferrer, M., 2015. What to avoid to succeed as an entrepreneur. J. Bus. Res. 68 (11), 2279-2284.

McGee, J.E., Peterson, M., Mueller, S.L., Sequeira, J.M., 2009. Entrepreneurial selfefficacy: refining the measure. Entrep. Theory Pract. 33 (4), 965-988.

Miao, C., Qian, S., Ma, D., 2017. The relationship between entrepreneurial self-efficacy and firm performance: a meta-analysis of main and moderator effects. J. Small Bus. Manag. 55 (1), 87-107.

Moreno-Jiménez, B., Gálvez-Herrera, M., Garrosa-Hernández, E., Rodríguez-Carvajal, R., 2005. La adicción al trabajo. Psicol. Conduct. 13 (3), 417-428.

Morrison, A., 2006. A contextualisation of entrepreneurship. Int. J. Entrep. Behav. Res. 12 (4), 192-209.

Moyer, F., Aziz, S., Wuensch, K., 2017. From workaholism to burnout: psychological capital as a mediator. Int. J. Workplace Health Manag. 10, 213-227.

Mudrack, F.E., Naughton, T.I., 2001. The assessment of workaholism as behavioural tendencies: scale development and preliminary empirical testing. Int. J. Stress Manag. 8 (2), 93-111.

Mudrack, P.E., 2006. Understanding workaholism: the case of behavioral tendencies. In: Burke, R.J. (Ed.), Research Companion to Working Time and Work Addiction. Edward Elgar Publishing, UK, pp. 108-128.

Naughton, T.J., 1987. A conceptual view of workaholism and implications for career counselling and research. Career Dev. Q. 35 (3), 180-187.

Ng, T.W., Sorensen, K.L., Feldman, D.C., 2007. Dimensions, antecedents, and consequences of workaholism: a conceptual integration and extension. J. Organ. Behav. 28 (1), 111-136

Oates, W.E., 1971. Confessions of a Workaholic: The Facts About Work Addiction. World Publishing Company, New York.

Oates, W., 1981. Excesive work. In: Mule, S.J. (Ed.), Behavior in Excess: an Examination of the Volitional Disorders. Free Press, New York, pp. 264-272.

Omorede, A., Thorgren, S., Wincent, J., 2015. Entrepreneurship psychology: a review. Int. Entrep. Manag. J. 11 (4), 743-768.

Palmer, C., Niemand, T., Stöckmann, C., Kraus, S., Kailer, N., 2019. The interplay of entrepreneurial orientation and psychological traits in explaining firm performance. J. Bus. Res. 94, 183-194.

Peters, M., Pfurtscheller, A., Wong, K., Kraus, S., 2010. The influence of entrepreneurial branding on entrepreneurial/growth orientations: an empirical study in the Austrian tourism industry. Int. J. Bus. Res. 10 (2), 28-29.

Peters, M., Kallmuenzer, A., 2018. Entrepreneurial orientation in family firms: the case of the hospitality industry. Curr. Issues Tour. 21 (1), 21-40.

Piotrowski, C., Vodanovich, S.J., 2006. The interface between workaholism and workfamily conflict: a review and conceptual framework. Organ. Dev. J. 24 (4), 84.

Pikkemaat, B., Peters, M., Chan, C.S., 2018. Needs, drivers and barriers of innovation: the case of an alpine community-model destination. Tourism Manage. Perspect. 25, 53-63.

Podsakoff, P.M., MacKenzie, S.B., Lee, J.Y., Podsakoff, N.P., 2003. Common method biases in behavioral research: a critical review of the literature and recommended remedies. J. Appl. Psychol. 88 (5), 879.

Podsakoff, P.M., Organ, D.W., 1986. Self-reports in organizational research: problems and prospects. J. Manage. 12 (4), 531-544.

Porter, G., 1996. Organizational impact of workaholism. Suggestions for researching the negative outcomes of excessive work. J. Occup. Health Psychol. 1, 70-84.

Porter, G., 2006. Profiles of workaholism among high-tech managers. Career Dev. Int. 11 (5), 440-462.

Priede-Bergamini, T., López-Cózar-Navarro, C., Benito-Hernández, S., Rodríguez-Duarte, A., Platero, M., 2019. The dual effect of the age of the entrepreneur on the innovation performance of the micro-enterprises. Int. J. Entrep. Ventur. 11 (1), 81-102.

Reynolds, P., Bosma, N., Autio, E., Hunt, S., DeBono, N., Servais, I., et al., 2005. Globa entrepreneurship monitor: data collection design and implementation 1998-2003. Small Bus. Econ. 24 (3), 205-231.

Robinson, B.E., 1989. Work Addiction. Health Communications, USA.

Robinson, B.E., 1997. Work adiction: implications for EAP counseling and research. Empl. Assist. Q. 12, 1-13.

Robinson, B.E., 1999. The work addiction risk test: development of a tentative measure of workaholism. Percept. Mot. Skills 88, 199-210.

Robinson, B.E., 2000. Workaholism: bridging the gap between workplace, sociocultural, and family research. J. Employ. Couns. 37, 31-47.

Roldán, J.L., Sánchez-Franco, M.J., 2012. Variance based structural equation modeling: guidelines for using partial least squares in information systems research. In: Mora, M., Gelman, O., Steenkamp, A., Raisinghani, M. (Eds.), Research Methodologies, Innovations and Philosophies in Software Systems Engineering and Information Systems. Information Science Reference, Hershey, PA, pp. 193-221.

Rosseel, Y., 2012. Lavaan: an R package for structural equation modeling and more. Version 0.5-12 (BETA). J. Stat. Softw. 48 (2), 1-36.

Rumelt, R.P., 1991. How much does industry matter? Strateg. Manage. J. 12 (3), $167-185$.

Sajilan, S., Hadi, N.U., Tehseen, S., 2015. Impact of entrepreneur's demographic characteristics and personal characteristics on firm's performance under the mediating role of entrepreneur orientation. Rev. Integr. Bus. Econ. Res. 4 (2), 36.

Salanova, M., Del Líbano, M., Llorens, S., Schaufeli, W.B., Fidalgo, M., 2008. La adicción 
al trabajo (Workaholism), Nota Técnica de Prevención, 759, 22 Serie. Instituto Nacional de Seguridad e Higiene en el Trabajo, Madrid.

Sánchez-Medina, A.J., Melián González, A., García Falcón, J.M., 2007. Intellectual capital and sustainable development on islands: an application to the case of Gran Canaria. Reg. Stud. 41 (4), 473-487.

Satorra, A., Bentler, P.M., 2001. A scaled difference chi-square test statistic for moment structure analysis. Psychometrika 66 (4), 507-514.

Satorra, A., 2003. Power of $\chi 2$ goodness-of-fit tests in structural equation models: the case of non-normal data. In: Yanai, H., Okada, A., Shigemasu, K., Kano, Y., Meulman, J.J. (Eds.), New Developments in Psychometrics. Springer, Tokyo, pp. 57-68.

Schaufeli, W.B., Salanova, M., González-Romá, V., Bakker, A.B., 2002. The measurement of engagement and burnout: a two sample confirmatory factor analytic approach. J. Happiness Stud. 3 (1), 71-92.

Schaufeli, W.B., Shimazu, A., Taris, T.W., 2009. Being driven to work excessively hard: the evaluation of a two-factor measure of workaholism in the Netherlands and Japan. Cross-Cultural Res. 43 (4), 320-348.

Schaufeli, W.B., Taris, T.W., Van Rhenen, W., 2008. Workaholism, burnout and engagement: three of a kind or three different kinds of employee well-being? Appl. Psychol. 57 (2), 173-203.

Schumpeter, J.A., 1934. Change and the entrepreneur. In: Schumpeter, J.A. (Ed.), Essays of JA Schumpeter. Addison-Wesley Press, USA.

Scottl, K.S., Moore, K.S., Miceli, M.P., 1997. An exploration of the meaning and consequences of workaholism. Hum. Relat. 50 (3), 287-314.

Shaver, K.G., 2003. The social psychology of entrepreneurial behavior. In: Acs, Z.J., Audretsch, D.B. (Eds.), Handbook of Entrepreneurship Research. Springer, New York, pp. 331-357.

Shaw, G., 2008. Entrepreneurial cultures and small business enterprises in tourism. In: Lew, A.A., Hall, C.M., Williams, A.M. (Eds.), A Companion to Tourism. Richmond, UK, pp. 122-135.

Sierra Bravo, R., 1991. Técnicas de investigación social. Teoría y ejercicios. Paraninfo, Madrid.

Snir, R., Harpaz, I., 2004. Attitudinal and demographic antecedents of workaholism. J. Organ. Chang. Manag. 17, 520-536.

So, K.K.F., King, C., Sparks, B.A., Wang, Y., 2013. The influence of customer brand identification on hotel brand evaluation and loyalty development. Int. J. Hosp. Manag. 34, 31-41.

Solvoll, S., Alsos, G.A., Bulanova, O., 2015. Tourism entrepreneurship-Review and future directions. Scand. J. Hosp. Tour. 15 (1), 120-137.

Spence, J.T., Robbins, A.S., 1992. Workaholism: definition, measurement and preliminary results. J. Pers. Assess. 58, 160-178.

Sprankle, J.K., Ebel, H., 1987. The Workaholic Syndrome. Walker, New York.

Stephan, U., 2018. Entrepreneurs' mental health and well-being: a review and research agenda. Acad. Manag. Perspect. 32 (3), 290-322.

Strobl, A., Peters, M., 2013. Entrepreneurial reputation in destination networks. Ann. Tour. Res. 40, 59-82.

Sydler, R., Haefliger, S., Pruksa, R., 2014. Measuring intellectual capital with financial figures: Can we predict firm profitability? Eur. Manag. J. 32 (2), 244-259.
Taris, T.W., Geurts, S.A.E., Schaufeli, W.B., Blonk, R.W.B., Lagerveld, S., 2008. All day and all of the night: the relative contribution of workaholism components to wellbeing among self-employed workers. Work Stress 22, 153-165.

Teece, D.J., 2000. Strategies for knowledge assets: the role of the firm structure and industrial context. Long Range Plann. 33 (1), 35-54.

Thomas, R., Shaw, G., Page, S.J., 2011. Understanding small firms in tourism: a perspective on research trends and challenges. Tour. Manag. 32 (5), 963-976.

Unger, J.M., Rauch, A., Frese, M., Rosenbusch, N., 2011. Human capital and entrepreneurial success: a meta-analytical review. J. Bus. Ventur. 26 (3), 341-358.

Van de Ven, A.H., Hudson, R., Schoroeder, D.M., 1984. Designing new business start-ups: entrepreneurial, organizational and ecological considerations. J. Manage. 10, 87-107.

van der Zwan, P., Hessels, J., Rietveld, C.A., 2018. Self-employment and satisfaction with life, work, and leisure. J. Econ. Psychol. 64, 73-88.

Van Ness, R.K., Seifert, C.F., 2016. A theoretical analysis of the role of characteristics in entrepreneurial propensity. Strateg. Entrep. J. 10 (1), 89-96.

van Wijhe, C., Peeters, M., Schaufeli, W., Ouweneel, E., 2013. Rise and shine: recovery experiences of workaholic and nonworkaholic employees. Eur. J. Work. Organ. Psychol. 22, 476-489.

Van Zyl, J.H., Lotz, J.O., 2008. Harvesting everyday strategies with the end in mind. In: International Council for Small Business (Ed.). ICSB World Conference Proceedings.

Wang, C.J., Tsai, H.T., Tsai, M.T., 2014. Linking transformational leadership and employee creativity in the hospitality industry: the influences of creative role identity, creative self-efficacy, and job complexity. Tour. Manag. 40, 79-89.

Wennberg, K., Wiklund, J., DeTienne, D.R., Cardon, M.S., 2010. Reconceptualizing entrepreneurial exit: divergent exit routes and their drivers. J. Bus. Ventur. 25 (4), 361-375.

Wiklund, J., Davidsson, P., Audretsch, D., Karlsson, C., 2011. The future of entrepreneurship research. Entrep. Theory Pract. 35 (1), 1-9.

Wiklund, J., Patzelt, H., Shepherd, D.A., 2009. Building an integrative model of small business growth. Small Bus. Econ. 32 (4), 351-374.

OMT, 2018. UNWTO Tourism Highlights 2018. pp. 1-20. https://doi.org/10.18111/ 9789284419876.

Wrzesniewski, A., McCauley, C., Rozin, P., Schwartz, B., 1997. Jobs, careers, and callings: people's relations to their work. J. Res. Pers. 31 (1), 21-33.

Wurthmann, K., 2014. Business students' attitudes toward innovation and intentions to start their own businesses. Int. Entrep. Manag. J. 10 (4), 1-21.

Zhang, T., Acs, Z., 2018. Age and entrepreneurship: nuances from entrepreneur types and generation effects. Small Bus. Econ. 51 (4), 773-809.

Zhang, Y., Duysters, G., Cloodt, M., 2014. The role of entrepreneurship education as a predictor of university students' entrepreneurial intention. Int. Entrep. Manag. J. 10 (3), 623-641.

Zhao, H., Seibert, S.E., 2006. The big five personality dimensions and entrepreneurial status: a meta-analytical review. J. Appl. Psychol. 91 (2), 259.

Zhao, H., Seibert, S.E., Lumpkin, G.T., 2010. The relationship of personality to entrepreneurial intentions and performance: a meta-analytic review. J. Manage. 36 (2), 381-404. 